\title{
DESIGN CHARACTERISTICS OF NATURAL MOTIVES IN VARIOUS DECORATIVE AND MINANGKABAU TRADITIONAL EMBROIDERY
}

\author{
Yuliarma ${ }^{1}$, Wakhinuddin $\mathbf{S}^{2}$ \\ ${ }^{1}$ Departemen of Fakultas Pariwisata dan Perhotelan (FPP), \\ ${ }^{2}$ Departement of Engineering (FT) \\ Universitas Negeri Padang, Indonesia \\ yuliarmaincim@yahoo.com \\ wakhimuddins@gmail.com
}

\begin{abstract}
This research aims to inventory and dig some design characteristic of motif at needlework and natural embroidery of Minangkabau tradition and philosophical meaning as well as aesthetic value by using qualitative and desk study approach. The research was carried out in an industrial district of small and medium enterprises (SMEs) needlepoint and embroidery of West Sumatra (50 Kota District, Agam, Pariaman, and Solok); and the object of research is the needlework design and embroidery of Minangkabau tradition and products. Data collection through the study of literature, observations record, interviews, and documentation. The results showed: 1) the characteristics of natural motifs in decorative needlework and embroidery of Minangkabau in the center of SMEs in 50 Kota have chrysanthemum flower, jasmine flower and pumpkin flowers; Agam area with big roses (rosa spp, small roses (rosacanina) and hibiscus (Hibiscus rosa-sinensis)), dahlia (dahlia sp.); Pariaman area with chrysanthemum flower, stem fern (pterydophyta), tampuak mangosteen (Garcinia mangostana), pucuk rabung (bamboo shoots), chrysanthemums (Chrysanthemum morifolium); Solok area with yellow cempaka flowers (Magnolia champaca); 2) Character of embroidery motif composition needlework and Minangkabau embroidery in the center of SMEs at 50 City district have triangle shape of pucuk rabung (bamboo shoots) and decorative free patterns of products to casual baju kurung or kebaya (bracket-clothes); Agam area with a rectangular shape in the casual long dress (kebaya) product and customed stoles shawls, a circular shape on the casual kebaya product and mukena, decorative pattern on the edge of the walking and climbing; Pariaman area with a circle forms and a free form to filling full field (balapak) in the product of clothes custom products and custom stoles scarves, decorative patterns and sow the edge running full; Solok area with rectangular shape and fill the full field (balapak) on custom wedding products, ornamental patterns on the edge is walking and climbing;
\end{abstract}

Keywords: design characteristics of natural motifs, decorative needlepoint and traditional minangkabau embroidery.

\section{INTRODUCTION}

Art craft traditions of the embroidery and needlework live and grow in a Minangkabau society which is now developing into centers of craft industry 
needlepoint and embroidery are spread in almost every district / city, such as the area Kotogadang, Agam, 50 Kota, Naras pariaman, Lubuk begalung Padang, Sungayang Tanah Datar and Solok. Each region with their needlepoint product and embroidery have specific model in creating an ornate design that is associated with decorative motifs, colors and decorative techniques ((Yuliarma, 2002, 2004, 2015, 2017).

In the decorative arts reveal a set of costumed clothing fabrics, not all of the techniques and embodied designs is the same, but differ according to the function and place of origin creators culture. The difference was caused partly from the influence of the art background and culture and the development of different communities in creating art and fashionn decoration design. Chinese influence is clearly visible in the art of embroidery suji patterns and pinhead and color management in the traditional decoration fabrics (Biranul Anas, 1995: 19). Besides the influence of India, the Middle East and the Netherlands also serves to introduce suji embroidered, liquid suji and overlay the Minangkabau people, especially in areas of Kotogadang Agam. Embroidery art developments in progress and famous refer to Minangkabau tradition even reaches the land of Dutch exports at the beginning of the 18th century (Sativa sutan Azwar, 1999).

But until now as the works of art belonging to the Minangkabau culture, there is no written information of comprehensive documentation about the Minangkabau traditional needlework design and embroidery (Yuliarma, 2015, 2017). Even the artwork is feared this culture will disappear and become the property of another State.

This a very serious problem and need to be addressed are some types of embroidery and traditional design has been difficult to find, even traditional motifs maker in the centre of SMEs has already scarce; likewise with Embroidery and needlework traditional design. As a result of the globalization of embroidery products competitors from China, Turkey, Korea, Malaysia and other Asean countries to become more frequent and feared the characters of traditional Minangkabau needlepoint and embroidery increasingly unfamiliar and even be easily lost. Therefore, in order not to trigger lost one of Indonesian art asset and very popular and famous culture, it is necessary to study the characteristics of needlework designs and embroidery Minangkabau, particularly the design characteristics of natural motifs in decorative needlework and traditional embroidery Minangkabau philosophical meaning and aesthetic value.

Problems of needlework designs wealth and Minangkabau tradition embroidery, needs to be addressed immediately in anticipation of copyright protection (IPR), Because it is very necessary to study and do an inventory research of needlepoint and embroidery designs of Minangkabau tradition from West Sumatra. The result of inventory in addition to be Minangkabau culture copyright, also embody the identity or character of a unique cultural product of Minangkabau art that have aesthetic value that born of the society life and should be preserved.

The purpose of this study is to inventory and reveal the characteristic of decorative needlework motif of Minangkabau tradition embroidery and philosophical meaning as well as aesthetic values. 


\section{LITERATURE REVIEW}

\section{a. Needlework and Embroidery}

The term embroidery is identical to embroider because the word "embroidery" is taken from the English. Judging from the engineering work on the embroidery is a decorating technique background fabric by sewing thread decoratively by using the fingers of the hand, thus forming the decorative motifs or patterns (Wasia Roesbani, 1991). While embroidery is an element to change the surface appearance of fabric with various stitch embroidery is done by machine ( Yuliarma, 2014).

\section{b. Various Decorative Techniques}

Various of decorative techniques in the embroidery designs, including: embroidery suji. Fantasy embroidery, needlepoint china (suji, liquid suji), ribbon embroidery, needlepoint pinhead, raised embroidery, shadow needlepoint, lekapan, overlay (Pulukadang, 1985; Yuliarma, 2016).

\section{c. Embroidery Designs and Embroidery}

Literally, the design is often interpreted as the result of a plan or design. Definition of design in fashion closely associated with fashion, namely: the arrangement of the elements of line, shape, pattern, color, size, and material, texture regularly from the desirability of an object, resulting in a product that is worth the quality of certain points (aesthetic), namely unity, harmony, symmetry, balance and contrast (The Liang Gie, 1983).

Tastes or public acceptance of the expression 'beauty' of a clothing design is always changed and very influenced by community lifestyle especially the growing acceptance of fashion. Likewise in the creation of aesthetic needlepoint and embroidery, that element of 'art' and 'fashion' are two very influential.

Based on the above definition can be interpreted that the needlework design and embroideryis part of a decorative design, ie arrangement of pattern, color, material and decorative techniques with the application of the design principles, composition and decorative motif placement follows the pattern of the product so as to produce aesthetic valuable products, functional, ergonomic and economical.

d. Various kinds of decorative patterns on the decorative design of needlework and embroidery, namely:

In decorating the Fashion products there are various ornamental patterns can be used in accordance with the decorated field, such as: (1) the fringe pattern, include: the pattern of standing roadside, depending roadside, symmetry edge, the walking and climbing edge (2) pattern filling out the fields, include: husky pattern, corner patterns, converge patterns and free patterns (Sipahelut, 1991).

\section{e. Concepts of Minangkabau Aesthetic}

Understanding art is often identified with subtlety, namely the expertise to make quality works. Art is the result of human creativity that is capable of inflicting and evocative aesthetic response, therefore the aesthetics may serve as reference for discussing and addressing the objects of cultural products, especially the products of arts (Jacques maquet in Widagdo, 2001: 3)

Traditional crafts is one of the products works of art, is the result of the manifestations that reflect to the religion rules, beliefs, customs and other cultural elements that have lived and evolved in the community (Sutrisno, 1989). That is, in addition to the influence of religion and custom, tradition craft designs on 
fabrics customary fashion as art and culture produced by the patchwork community and Minangkabau embroidery craft industry was influenced by other cultures interacted in the life of the community.

In the tradition of the Minangkabau culture, there are four basic conception of mutually supportive aesthetics in giving birth art works related to visual expression and content. Fourth conception of art that embraced by Minangkabau society as aesthetic concepts are (1) a way of life 'the nature become a teacher', (2) a thought system that became the norm or criterion assembled in 'Tungku nan tigo sajarangan,' (3) the principle of adat basandi syarak (custome related to Qur'an) in relation to the aesthetics concept of Islam, (4) with respect to materials, tools, and how to use that can be drawn from the expression of minang poetry (Ibenzani Usman, 1984: 136).

That is, the traditional values and religion into the concept of Minangkabau culture is the customs teaching that are based on the Islam religion which is expressed through the philosophy of "Minang "Adat basandi syarak, syarak basandi Kitabullah" and a view of life that starts at the nature oriented attitude is formulated by the adage "Nature become a teacher "as well as the mindset of" Tungku Tigo Sajarangan "in Minangkabau reasoning as norms or criteria and expressions of traditional poetry. The fourth concept is revealed in the form of art and needlework and embroidery designs are born of Minangkabau tradition society that gave birth to the expertise of quality works.

Form the aesthetic decorative needlework design and Minangkabau embroidery products, covering: fabric ornament structure (motifs, colors and decorative techniques).

Furthermore, the principle of Minangkabau society life governed by: (1) The laws of customs, (2) Islamic Religion, and (3) the Act which is called Tali tigo Sapilin, Tungku tigo sajarangan (Yayasan Gebu Minang. (1993) and Idrus Hakimi (1994); which means in regulating the good life in the longhouse, in the community three of the above is the life principle that can not be separated or abandoned one. one other must be consistent, mutual support, mutual trust, mutual cooperation, consensus, consultation and cooperation.

\section{RESEARCH METHODOLOGY}

Research methods are descriptiv qualitative and desk study approach to examine the character of the needlework design and Minangkabau tradition embroidery as well as philosophical meaning. The research was done in the creative industries of SME centers in the sector of needlepoint and embroidery of West Sumatra, covering area of culture growth and embroidery art and Minangkabau traditional embroidery, 4 district centers are SMEs of: 50 Kota District, Agam, Pariaman, and Solok. Data collected through the literature study, observations record, interviews, and documentation study.

\section{RESULTS AND DISCUSSION}

As a result of Minangkabau traditional art, needlework and embroidery has individual own characteristics and distinguishes it from other regions. In these

discussions would be disclosed: natural motif design characteristics on a Minangkabau traditional decorative variety of needlework and embroidery at the center of the creative industry and philosophy meaning of aesthetic value. 


\section{a. Characteristics of natural motifs in the Needlework Designs And Minangkabau tradition Embroidery}

\section{1) Characteristics of natural motifs on the Needlework and Embroidery Designs at SMEs of 50 Kota District}

The results of the data analysis of 32 embroidery products crafts in the center of SME at $50 \mathrm{Kota}$, in fact the ideas of various decorative motif is derived from plants form and flower (naturalist form), including the type of lily (Nymphaea spp) 1 product (3.13\%), pumpkin Flowers (Cucurbita moschata) 5 product (15.63\%), grapes (Vitis vinivera) 1 product (3.13\%), chrysanthemums (Chrysanthemum morifolium) 9 product (28.125\%), jasmine (Jasminum sambac) 5 product (15.63\%), banana-canna (Canna var) 1 product (3.13\%), rose (rosa spp) 3 product $(9.375 \%)$, Dahlia flower (Dahlia sp.) 1 product (3.13\%) tulips (Tulipa) 1 product (3.13\%), Imperata flowers (Imperata cylindrica) 1 product (3.13\%), cats Flowers whiskers (orthosiphon aristatus) 1 product $(3.13 \%)$, of yellow frangipani flowers (Magnolia champaca) 2 product $(6.25 \%)$, flower knob or fennel-anise (Gomphrena globosa) 1 product (3.13\%), flowers and leaves of papaya (papaya cacarica) 1 product $(3.13 \%)$. There are 14 types of flowers tend to have distillation for embroidery decorative motif in the District of 50 Kota, however, the type of chrysanthemum flower, jasmine flower and pumpkin flowers often tends to be a distillation source of motif ideas for embroidery; so that it becomes a center motif character of embroidery products in the center of SMEs of 50 Kota district.

From the data ornamental arrangement patterns of embroidered motifs on the product, turns 31 product $(96.875 \%)$ tends to free chest motif design with 27 product $(84.375 \%)$ developed a triangle shape pucuk rabung (bamboo shoots motif) and 2 product ( $6.25 \%$ ) rectangular shape, one product $(3.125 \%)$ to design clothes motive at the bottom edge with an edging decorative pattern with the kebaya (bracket clothes) stand. It has been suggested that the character of a decorative pattern of embroidery products are free decorative patterns, triangles with pucuk rabung (bamboo shoots). Examples of product design characteristics and traditional embroidery motif in the center of District 50 town can be seen in Figure 1.

\section{2) Characteristics of natural motifs in The Needlework Designs And Embroidery in The SMEs centers of Agam}

The results of the data analysis of 19 embroidery products at the center of SME Agam turns the decorative motif ideas tend to come from plants form and flower (naturalist form). The idea motif inspired from 8 types of flower include: Hibiscus Flower (Hibiscus rosa-sinensis) 3 product (15.789\%), Small Roses (rosacanina) 5 product $(26.315 \%)$, Dahlia Flower (Dahlia sp.) 1 product $(5.263 \%$ ), water jasmine (Echinodoruspalaefolius) 1 product $(5.263 \%)$, (Impatiens balsamina L) 1 product $(5.263 \%)$, jasmine (Jasminum sambac) 2 product (10.526\%), roses (rosa spp) 6 product $(31.579 \%)$, yellow frangipani flowers (Magnolia champaca) 1 product $(5.263 \%)$ and one of Abstract product form (5.263\%). However, this type of large rose flowers, rosettes, and hibiscus often distilled into a source of embroidered motif ideas. It has been suggested that the large rose flower motif, rosettes and hibiscus is a mainstay motif that characterizes the product embroidery craft in SME of Agam centers, 
Viewed composition decorative pattern of embroidered motif on the women clothes products, turns 11 products $(26.32 \%)$ tends to design motif clothes to the chest with triangles form with ornamental patterns depend (inspired by the shape of a triangle or pucuak rabuang, and the edge pattern by climbing rectangular as much as 5 products $(26.32 \%)$, and the semicircle 5 products $(26.32 \%)$ to design long scarf, and 3 products $(15.79 \%)$ free patterns, one product $(5.26 \%)$ converging pattern. It means that the decorative patterns depend triangles of pucuk rabung (bamboo shoots) to design the arrangement of the chest part of the women shirt motif with climbing edging pattern rectangle shape and a semi-circle to decorate the long scarf products and long dress that are Agam characteristic. (See the directory embroidery designs of Agam Minangkabau region in the annex). Examples of product and design natural motif characteristics on traditional embroidery in Agam District can be seen in figure 2.

\section{3) Natural Motif Design Characteristics on the Needlework and Traditional Embroidery in SME centers of Pariaman}

Of the 28 products were taken from the embroidery crafts center of SME Pariaman turns the decorative motif ideas tend to come from the plants and flowers form, animals and geometric (naturalist and geometric shapes). The motif idea is inspired from 11 types of flowers that grow in the environment of centers area, include: chrysanthemums flowers (Chrysanthemum morifolium) 5 product (17.857\%), mangosteen flowers (Garcinia mangostana) 7 product (25\%), Leaf spikes (pterydophyta) 16 product $(57.14 \%)$, bamboo shoots 5 product (17.86\%), Mangosteen (Garcinia mangostana) 1 product (3.571\%), small roses (rosacanina) 4 product (14.285\%), Dahlia flower (Dahlia sp.) 1 product (3.571\%), Dara Tread Flower (Catharanthus roseus) 1 product (3.571\%), jasmine (Jasminum sambac) 2 product $(7.143 \%)$, roses (rosa spp) 3 product (10.714\%), and yellow cempaka (Magnolia champaca) 3 product (10.714\%). As well as a phoenix 3 product $(10.714 \%)$, two types of geometric motifs include: a circular shape (consensus / mutual assistance / cooperation) 1 product $(3.571 \%$ ) and rectangular (consensus / mutual assistance / cooperation) 1 product $(3.571 \%)$. It turns out that types of nails leaves, mangosteen flowers, pucuk rabung (bamboo shoots) and Chrysanthemum morifolium are the types of flowers that are often inspired to gold thread embroidery of Pariaman. Even the motive tends to be characteristic of the bridal customary fashion of Pariaman area.

Judging from the motif patterns character on the embroidered motif turns preparation tends to compose motifs and edging patterns and full sow motif (balapak motif in local language) triangle shape like pucuk rabung (bamboo shoots) 17 product $(60.71 \%)$, a rectangle, 8 products $(28,57 \%)$, forms a circle 2 products $(7.14 \%)$, and 2 products $(7.14 \%)$ with pattern of filling free field. That is, the edge of the decorative patterns and sow full (balapak) to form a triangular arrangement (bamboo shoots) and rectangular embroidered decorative patterns which characterize the Pariaman area. (Example product and natural motif design characteristics on the Minangkabau embroidery of Pariaman area, see Figure 3.). 


\section{FPP-UNP}

\section{4) Characteristics Embroidery Designs And Embroidery The SME centers Solok}

The results of the data analysis from 6 embroidery products at the center of SME Solok turns the decorative motif ideas tend to come from the plants and flower form (naturalist form) are available in the environment. There are 5 types of florals tend to distillation for embroidery motifs that show the embroidery motif characteristic, covers motif: yellow frangipani flowers (Magnolia champaca) 2 product (33.33\%), pumpkin flowers (Cucurbita moschata) 1 product (16.67\%), the rose (Rosa spp.) 1 product (16.67\%), small roses (rosacanina) 1 product (16.67\%), geometric circle 1 product $(16.67 \%)$. Not many types of products that can be analyzed because the embroideries center of SME in Solok are many who do not produce themselves, but of the six types of products found as the pumpkin flowers motif, jasmine and yellow campaca flower, ros flower already showing the characteristics of plant products that exist in the environment of Solok. Yellow frangipani campaca motif (Magnolia champaca) is more often used for products, which indicates that the characteristic of this embroidery motif is the most find in the area of Solok.

Viewed over a motif decorative pattern tends to use a pattern fill in the free form with vertical lines, circles, triangles, rectangles and climbing edging pattern. However, the decorative patterns are often used to the edging pattern, filling the full field (balapak), triangle shape with pucuk rabung (bamboo shoots) that shows the character of SMEs ornate design decorative patterns of embroidery in the area of Solok (Example product and natural motif design characteristics on Minangkabau embroidery of Pariaman area, see figure 4).

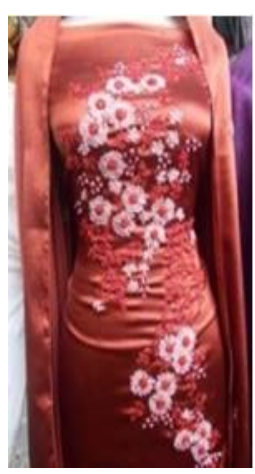

(a) baju kurung model

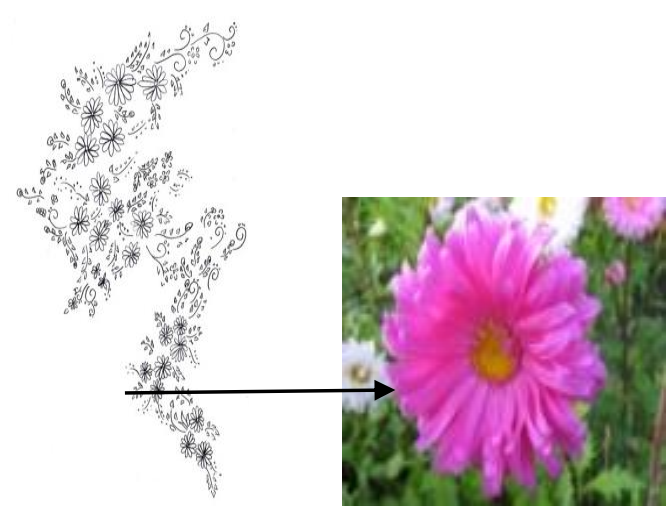

(b) decorative pattern (c) chrysanthemum

Flower character inspiring

Figure 1 : Example of a natural motif design inspirited by Chrysanthemum (Chrysanthemum Morifolium) On the raised embroidered clothing products refer to kebaya in the center of 50 Kota 


\section{FPP-UNP}

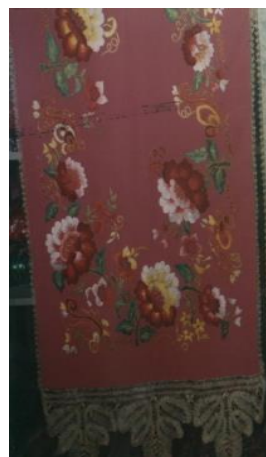

(a) Shawl model

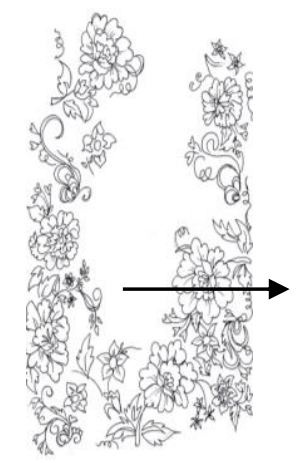

(b) decorative pattern

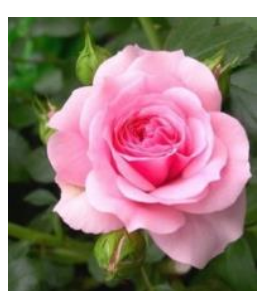

(c) roses flower character

Figure 2 .: Example of a inspiring natural motif design of big roses (rosa spp) on Liquid suji embroidered to the long scarf product in the center of SME of Agam District

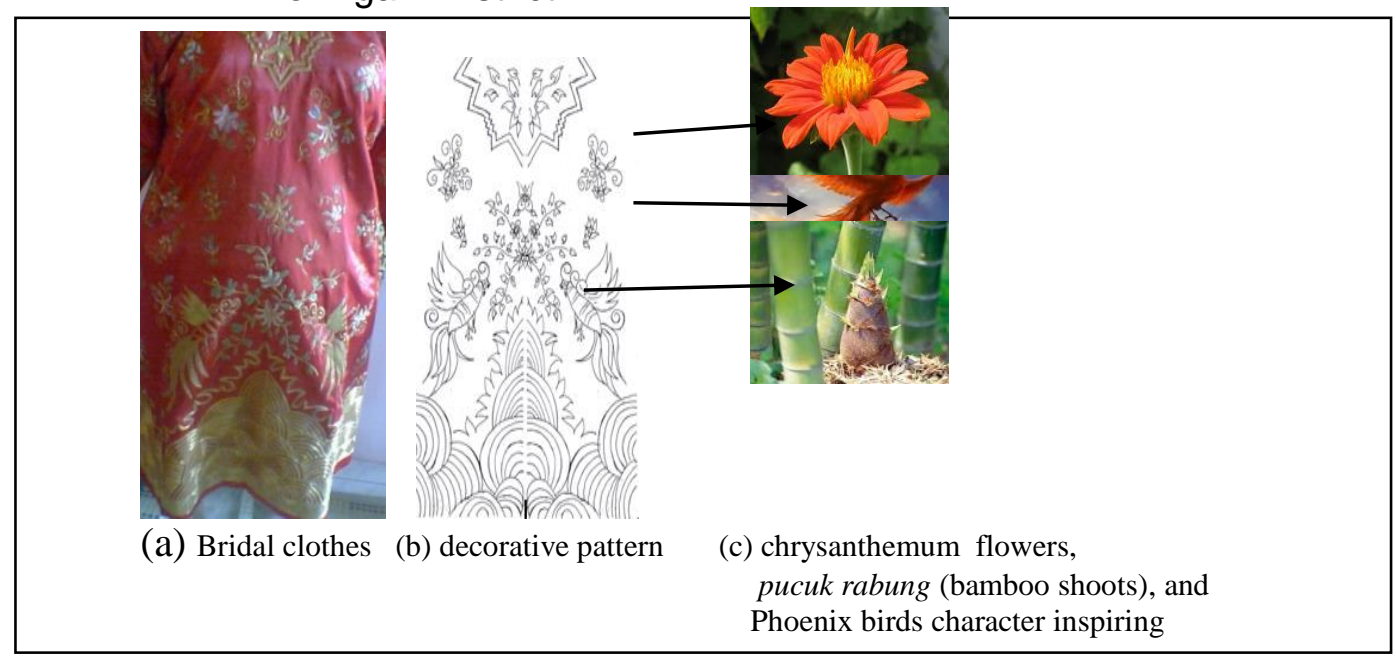

Figure .3: Inspiring Motif Design of Chrysanthemum morifolium flowers on Embroidered product of baju kurung bridal in SME centers of Pariaman
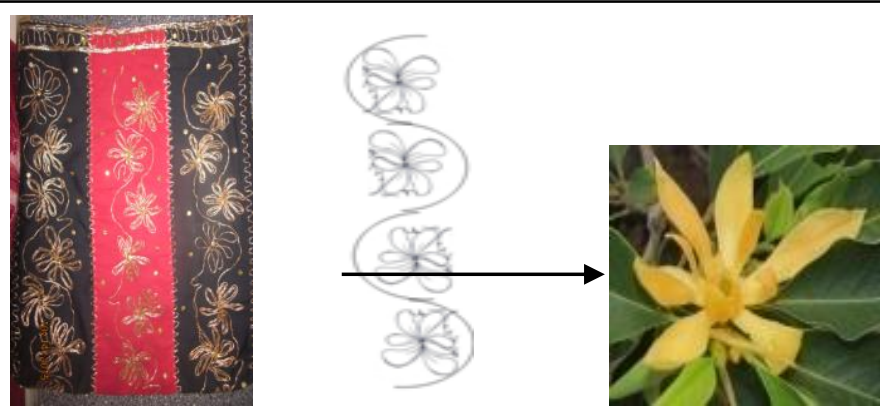

(a)Pelaminan (wedding) (b) decorative pattern (c) yellow frangipani flowers Character nspiring

Figure .4: Characteristics of a inspiring natural motif design with yellow frangipani flowers on the product of long dress in the SME centers of Solok 


\section{CONCLUSION}

The results of this study concluded that the value of motifs design aesthetic of nature on the needlepoint products and embroidery at the center of the creative industry 50 Kota, Agam, Pariaman, and Solok is an esthetic arrangement of needlepoint motif and embroidery visualized: revealing functional objects made, social status, class, cultural object that contains and expresses an attitude and way of minangkabau society life in the local community. Finding this study showed:

1.Characteristics of natural motifs in a various decorative embroidery of Minangkabau tradition: 50 kota districts area with big roses (rosa spp), dahlia flower (dahlia sp.), and the lotus (Nymphaea spp); Agam area with large roses (rosa spp), rosettes (rosacanina) and hibiscus (Hibiscus rosa-sinensis); the Pariaman area with Yellow Magnolia flower (Magnolia champaca), fern (pterydophyta), mangosteen flower (Garcinia mangostana), pucuk rabung (bamboo shoots); and yellow frangipani flowers. In the Solok area (Magnolia champaca).

2. Characters arrangement of needlepoint motif and Minangkabau embroidery in the center SME of $50 \mathrm{Kota}$, characterized by triangle shape of pucuk rabung (bamboo shoots) and free decorative patterns of the kebaya casual products; Agam area with rectangular shape in the long dress (kebaya) product casual custom stoles and shawls, a circular shape on the product of casual clothes and mukena, edge decorative pattern of the walking and climbing; In Pariaman area find a circle form and a free form filling full field (balapak) in custom baju kurung or kebaya products and custom stoles scarves, decorative patterns and sow the edge running full; Solok area with rectangular shape and fill the full field (balapak) on custom wedding products, ornamental patterns with walking edge and climbing.

\section{REFERENCE}

Biranul Anas. (1995). Indonesia Indah: Kain-kain Non Tenun Indonesia 4. Jakarta:

Gie, The Liang. (1983). Garis Besar Estetik: Filsafat Keindahan. Yogyakarta: Supersukses.

Heskett, John.( 1986) Desain Industri, Terjemahan, INDDES ITB, Rajawali, Bandung: , Rajawali

Josseline De Jong. P.E.D.E. (1952). Minangkabau Negeri Sembilan: Socio - Political Structur in Indonesia. The Haque: M. Nijhoff.

Koentjaraningrat (1990). Pengantar Ilmu Antropologi. Jakarta: Rineka Cipta.

Nanang Rizali (2002). Kecenderungan Pasar Mode dan Perkembangan Mode Sebagai Alternatif Pendekatan Dalam Perancangan Tekstil Cetak. Bandung STISI.

Sativa Sutan Aswar . (1999). Antakesuma suji Dalam Adat Minangkabau. Jakarta: Djambatan.

Sipahelut, A dan Petrussumadi (1991). Dasar-Dasar Desain.

Sofwandi Mangkudilaga D. Dkk. (1983). Pameran Kain Minangkabau di Maseum Tekstil Jakarta.

Sutrisno. (1989). Kerajinan Tradisional Crafts Utilize The Natural Environment). Jakarta: Depdikbud Dirjen Kebudayaan Museum Nasional. 


\section{FPP-UNP}

Wasia Roesbani Pulu Kandang.(1991). Keterampilan Menghias Kain. Bandung: Angkasa

Wasia Roesbani Pulu Kandang.(1985). Keterampilan Menghias Kain. Bandung: Angkasa.

Widagdo. (2001). Seni Rupa, Jurnal Seni Rupa, Desain dan Kriya. Bandung: FSRD ITB.

Yayasan Gebu Minang. (1993). Minangkabau (West - Sumatera Indonesia). Jakarta : Gebu Mnang.

Yuliarma. (2002). Studi tetang Desain Hiasan Bordir di Kecamatan Tilatang Kamang, Kabupaten Agam. Padang: UNP.

--.-- (2004). Kajian desain Kain-kain tradisional Minangkabau (thesis). Bandung: Program Magister Desain ITB.

-. (2009). Laporan Penyusunan Peta Panduan Pengembangan Sentra IKM Kerajinan Bordir dan Sulaman Kota Payakumbuh.Diskoperindag Propinsi Sumatera Barat.

-. (2014). Desain Ragam Hias Sulaman Dan Bordir. Padang: UNP Press.

(2015). Inventarisasi Desain Sulaman dan Bordir Minangkabau, Identivikasi Masalah, dan Upaya Pengembangan Desain Tradisional Yang Akulturatif Serta Diversifikasi Produk Pada Sentra Industri Kreatif Sumatera Barat. Jakarta: Penelitian Unggulan Perguruan Tinggi Ditlitabmas, Ditjen Dikti Kemendikbud. -. (2016). The Art Of Embroidery Designs. Mendesain Motif Ragam Hias Bordir Dan Sulaman. Jakarta: KPG (Kepustakaan Populer Gramedia).

- (2017). Inventarisasi karakteristik desain sulaman dan bordir tradisional minangkabau dan identifikasi permasalahan desain, dan kreativitas sdm dalam mengembangkan desain dan diversifikasi produk pada sentra industri kreatif sumatera barat. Jakarta: Penelitian Unggulan Perguruan Tinggi Ditlitabmas, Ditjen Dikti Kemendikbud. 